\title{
Drainage effects on the transient, near-surface hydrologic response of a steep hillslope to rainfall: implications for slope stability, Edmonds, Washington, USA
}

\author{
G. Biavati ${ }^{1}$, J. W. Godt ${ }^{2}$, and J. P. McKenna ${ }^{2}$ \\ ${ }^{1}$ Dipartimento di Scienze della Terra e Geologico-ambientali, Università di Bologna, Italy \\ ${ }^{2}$ U.S. Geological Survey, Denver, Colorado, 80 225, USA
}

Received: 1 August 2005 - Revised: 25 January 2006 - Accepted: 25 January 2006 - Published: 11 May 2006

Part of Special Issue "Documentation and monotoring of landslide and debris flows for mathematical modelling and design of mitigation measures"

\begin{abstract}
Shallow landslides on steep $\left(>25^{\circ}\right)$ hillsides along Puget Sound have resulted in occasional loss of life and costly damage to property during intense or prolonged rainfall. As part of a larger project to assess landslide hazards in the Seattle area, the U.S. Geological Survey instrumented two coastal bluff sites in 2001 to observe the subsurface hydrologic response to rainfall. The instrumentation at one of these sites, near Edmonds, Washington, consists of two rain gauges, two water-content probes that measure volumetric water content at eight depths between 0.2 and $2.0 \mathrm{~m}$, and two tensiometer nests that measure soil-water suction at six depths ranging from 0.2 to $1.5 \mathrm{~m}$. Measurements from these instruments are used to test one- and twodimensional numerical models of infiltration and groundwater flow. Capillary-rise tests, performed in the laboratory on soil sample from the Edmonds site, are used to define the soil hydraulic properties for the wetting process. The field observations of water content and suction show an apparent effect of porosity variation with depth on the hydraulic response to rainfall. Using a range of physical properties consistent with our laboratory and field measurements, we perform sensitivity analyses to investigate the effects of variation in physical and hydraulic properties of the soil on rainfall infiltration, pore-pressure response, and, hence, slope stability. For a two-layer-system in which the hydraulic conductivity of the upper layer is at least 10 times greater than the conductivity of the lower layer, and the infiltration rate is greater than the conductivity of the lower layer, a perched water table forms above the layer boundary potentially destabilizing the upper layer of soil. Two-dimensional modeling results indicate that the addition of a simple trench drain to the
\end{abstract}

Correspondence to: G. Biavati

(biavati@geomin.unibo.it) same two-layer slope has differing effects on the hydraulic response depending on the initial pressure head conditions. For slope-parallel flow conditions, pressure head is significantly reduced near the drain; however, for transient, vertical infiltration in a partially saturated soil, conditions consistent with those observed during monitoring at the Edmonds site, the drain decreases the thickness of a perched water table by a small amount.

\section{Introduction}

Drainage is a principal physical measure used in mitigation of landslides (Hutchinson, 1977), because it is an economical and efficient way to alleviate positive pore-water pressures that promote slope failure (Forbes, 1947). Nevertheless, drainage systems are usually designed from practical experience, and the real effect of this mitigation system on slope stability is seldom quantified. Here we present an application of numerical flow modeling in the unsaturatedsaturated zone to assess the effectiveness of a drainage system. We emphasize that this type of investigation should only be carried out following analysis of the triggering factors on slope stability.

Rainfall-induced landslides constitute a well documented hazard in the Puget Lowland (i.e., Tubbs, 1974; Thorsen, 1989; Baum et al., 1998; Coe et al., 2004; Godt et al., 2006). Most landslides occur on steep bluffs that form much of the coastline of Puget Sound. These landslides threaten the railway corridor that runs between Seattle and Everett; during the winter season of 1996 and 1997 landslides caused disruption of railroad service (Baum et al., 1998). As part of a larger project to assess landslide hazards in the Seattle area,

Published by Copernicus GmbH on behalf of the European Geosciences Union. 


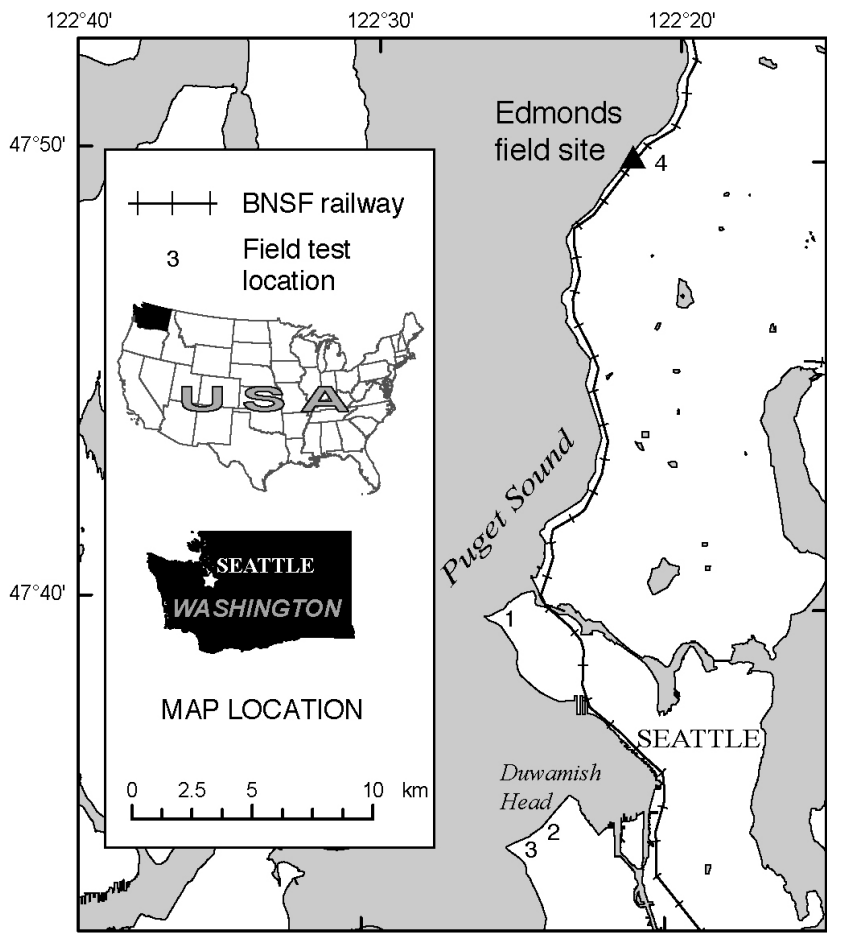

Fig. 1. Map showing the location of the study area near Edmonds, Washington, USA.

the U.S. Geological Survey began a monitoring campaign in 2001 to study the near-subsurface hydrologic response to rainfall. According to the classification of Varnes (1978), landslides along the rail corridor are earth slides, debris flows, rapid earthflows or combinations thereof (Baum et al., $2000)$. Typically the landslides are small $\left(<1000 \mathrm{~m}^{3}\right)$ failures of poorly consolidated, variably-sized colluvium which mantles the steep hillslopes in the area. The failure surface is frequently shallow ( $<3 \mathrm{~m}$ deep) and located near the contact between the colluvium and the underlying betterconsolidated layer (Tubbs, 1974; Miller, 1991; Baum et al., 2000). The study area is located about $5 \mathrm{~km}$ from the City of Edmonds, Washington (Fig. 1), along a steep bluff along Puget Sound, where one of the monitoring sites is located.

The hydrologic monitoring data from the Edmonds site during the 2001-2004 campaign shows that the porepressure response to rainfall is a transient process with a dominantly vertical component that takes place in partially saturated soil (Godt, 2004; Baum et al., 2005). Numerical or analytic models to simulate the transient pore-pressure response to rainfall have been used to study rainfall-induced landslides (i.e., Anderson and Howes, 1985; Reid et al., 1988; Brooks and Richards, 1994; Iverson, 2000; Baum et al., 2002). In this paper we examine the effect of physical and hydraulic properties on numerical simulations of flow in the unsaturated zone for a landslide-prone hillslope and we simulate how a simple drainage system may affect the hydrology of the hillslope during intense or prolonged rainfall.

\section{Geologic and geomorphologic setting}

The study area is located approximately $5 \mathrm{~km}$ northeast of the Port of Edmonds along a steep coastal bluff above Puget Sound. Puget Sound is located in the Puget Lowland, a broad north-south oriented basin that separates the Olympic Mountains to the west and the Cascade Range to the east. The surficial geology and geomorphology of the area are largely the product of the last glacial retreat which occurred about 15000 years ago (Porter and Swanson, 1998). Relief in the area extends from sea level to about $500 \mathrm{~m}$ in elevation, and the bluffs represent the partially eroded lateral deposits of the glaciers that formed the troughs eventually invaded by the ocean. Most of the hillslopes are composed of till, sands and silts deposited during the Vashon Stade of the Fraser Glaciation between about 17000 and 13500 years ago (Waldron et al., 1962), and are covered with colluvium derived from these same units. The stratigraphic units in the Vashon Stade, from the bottom to the top are (Troost et al., 2005): Lawton clay (Qvlc), a proglacial lacustrine silt and silty clay that marks the boundary between the nonglacial and most recent glacial period. This deposit is up to $30 \mathrm{~m}$ thick and is generally well fractured. The Advance Outwash (Qva) which is a very dense, clean, mostly gray, well stratified, sand that is up to $70 \mathrm{~m}$ thick and typically overlies the Lawton Clay with a transitional contact. The Vashon Till (Qvt) is a non-sorted, non-stratified diamict that underlies much of the upland area in Seattle. It has a variable particle size and is normally dense to very dense, gray, gravelly, silty sand or sandy silt, locally clayey with scattered cobbles. The weathering products of the Vashon Till are called Alderwood soil, a thin, highly permeable soil generally less than $1 \mathrm{~m}$ thick (Snyder et al., 1973). Finally, the Recessional Outwash (Qvr) is a mostly clean, well stratified, gray to oxidized sand and gravel generally only a few meters thick, deposited by the retreating Vashon glacier.

Most of the hillslopes are mantled by a colluvium with very poorly developed soil structure of variable thickness, that is generally less than $2 \mathrm{~m}$, on steep slopes (Troost et al., 2005). The particle size is typically dominated by sand, but ranges in size from boulders to clay; generally the clay and silt fraction is less than 20 percent. According to the Unified Soil Classification, the hillslope colluvium can be classified as silty sands (Galster and Laprade, 1991).

The climate of the Puget Lowland is typical of the Pacific Northwest of the United States with a pronounced seasonal precipitation regime and a winter precipitation maximum. Seattle, about $15 \mathrm{~km}$ south of Edmonds, receives about 74 percent of its total annual precipitation (an average of $963 \mathrm{~mm}$ for the period between 1972 and 1998) between November and April (Church, 1974). 

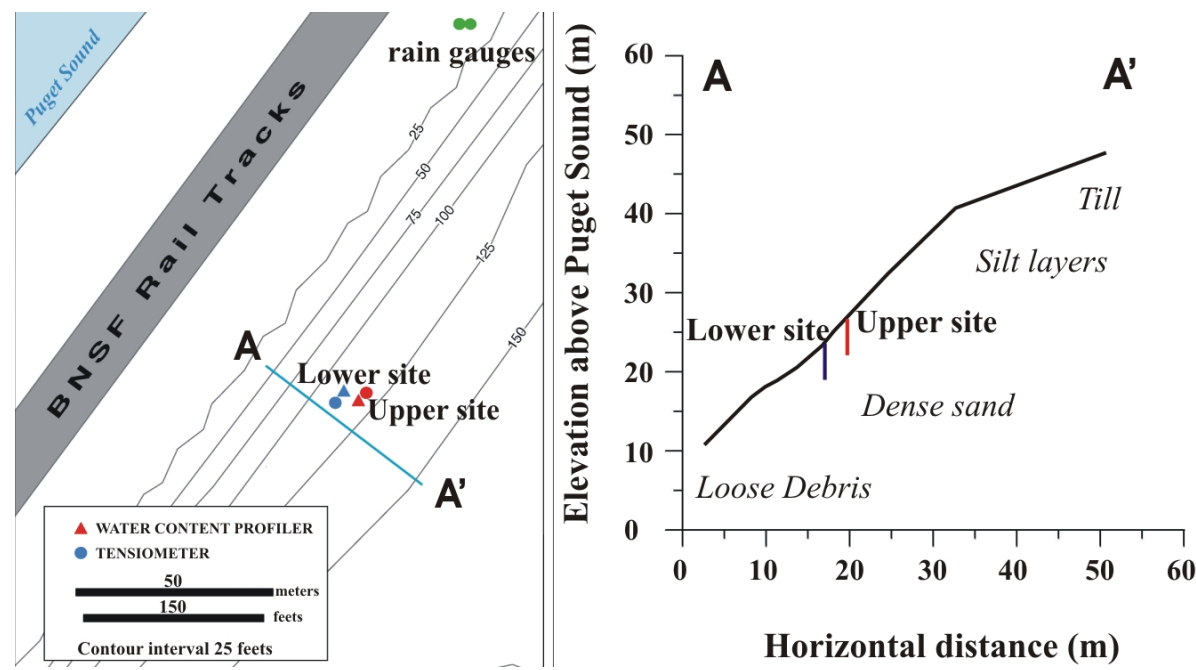

Fig. 2. Map and cross section of the monitored slope (modified from Baum et al., 2005).

\section{Landslide activity}

Most of the documented landslides near the study area have occurred in glacial sediments, including the Advance Outwash, till, and Lawton Clay (Baum et al., 2000). Although some recent landslides are deep-seated slides, shallow slides and debris flows are by far the most common (Baum et al., 2000, 2005). In the City of Seattle, Tubbs (1974) suggested that water perched in the Advanced Outwash Sand (Qva) by the generally less permeable and underlying Lawton Clay (Qvlc) makes the area near the contact between the two units preferentially susceptible to landslides during heavy rainfall. The contrast in soil hydraulic properties between typically loose surficial materials (colluvium and/or Advanced Outwash Sand (Qva)) that overly a less permeable substrate (i.e., Lawton Clay) provides a locus for shallow landslide failure, as infiltrating water may form a perched water table during heavy rainfall (Gerstel, 1996; Godt, 2004). Several landslides occurred in the Seattle area during the winter rainy season of 2001-2002 (Baum et al., 2005; Godt et al., 2006). Limited monitoring data available from that period of time confirmed that, although soil-water content fluctuated slightly in response to storms, it had risen to wet-season conditions prior to occurrence of prolonged, relatively intense precipitation associated with landslides that occurred in Seattle (Baum et al., 2005).

Heavy rainfall in the fall of 2003 brought flooding to the region, but little landsliding. Mount Baker-Snoqualmie National Forest estimates that October, 2003 floods resulted in $\$ 8$ million in damages to roads, trails, bridges and campgrounds (Brooks, 2003). Record 24-h rainfall measured at Sea-Tac international airport of 5.02 inches caused 15 counties to be declared federal disaster areas (Harrell and Craft., 2003). However both storms occurred at the beginning of the rainy season when ground conditions were relatively dry and few mudslides or landslides occurred. Some minor mudslides were reported as a result of the mid-October rainfall event, but widespread landsliding did not occur from either storm.

\section{Field monitoring site and collected data}

The Edmonds site is part of a U.S. Geological Survey nearreal-time landslide monitoring project along the SeattleEverett, Washington rail corridor (Baum et al., 2005). The field monitoring site is located on a $45^{\circ}$ slope of dense glacial outwash sand (Qva), mantled with a thin (10 to $20 \mathrm{~cm})$ loose weathered rind and colluvium. The instrumentation at the site consists of two rain gauges, two soil-moisture monitoring probes and two nests of tensiometers. The soil-moisture monitoring probes and the tensiometers are located near the middle of the slope within the Qva sand at 30-40 $\mathrm{m}$ above sea level. The instruments are installed in two arrays about $4 \mathrm{~m}$ apart (Fig. 2). The water-content profilers (Sentek EnviroSMART ${ }^{\mathrm{TM}}$ ) have sensors at eight depths, ranging from $20 \mathrm{~cm}$ to $200 \mathrm{~cm}$. These sensors measure soil capacitance (dielectric constant), which varies with volumetric soil-water content, reported as percentage of total soil volume (thus varying between the residual moisture content and the saturated water content of the soil).

The tensiometers (Soil Moisture Corp. Model \#2100F), which can measure both positive and negative (suction) pore pressures, are installed at depths ranging from $20 \mathrm{~cm}$ to $150 \mathrm{~cm}$. The precipitation gauges are located at the bottom of the slope about $150 \mathrm{~m}$ north of the instrumented hillslope. Data are collected every 15 min when it is raining more than $0.254 \mathrm{~cm}$ per hour until $4 \mathrm{~h}$ after the threshold is met. Otherwise, data are collected hourly and transmitted hourly to a USGS computer in Golden, Colorado. 


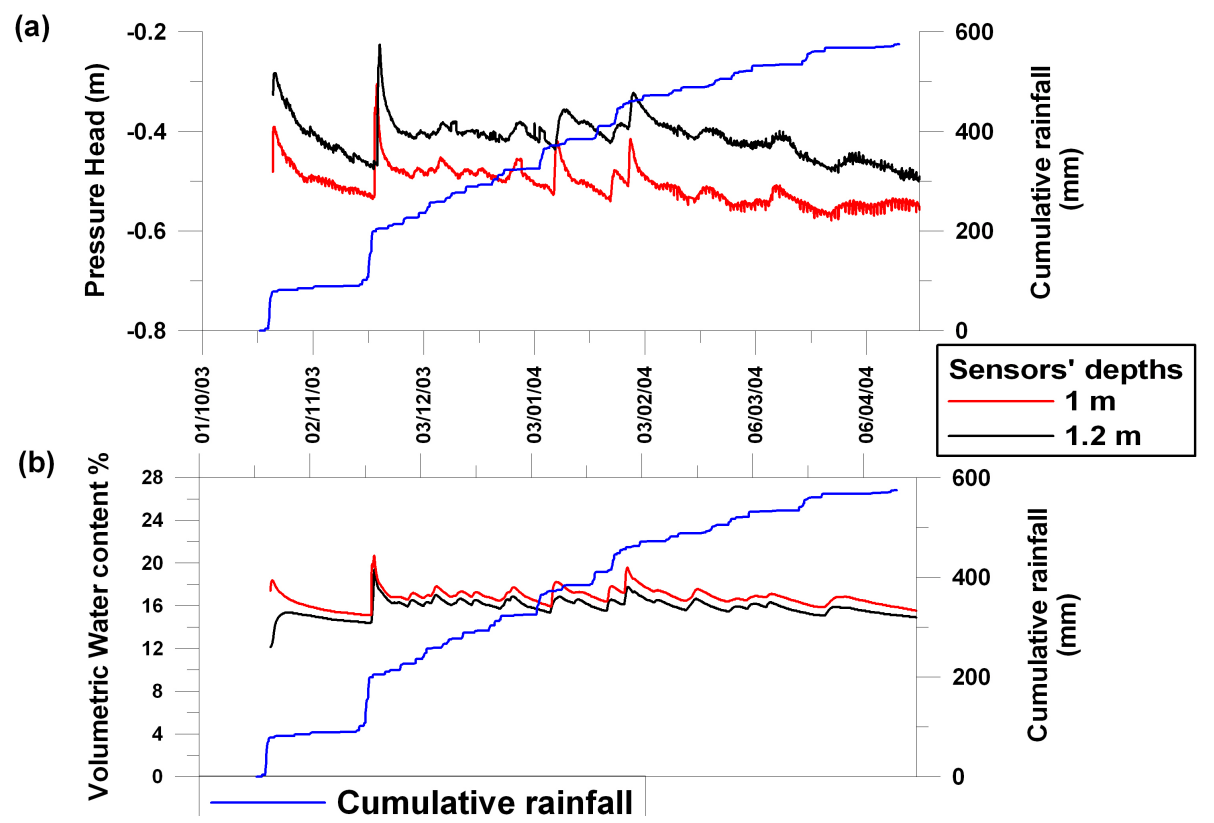

Fig. 3. Pressure head (a) and volumetric water content (b) of the soil collected at situ of the monitoring instruments installed in the upper part of the slope (modified from Baum et al., 2005).

Between 17 October 2003, and 21 April 2004, total rainfall recorded at the Edmonds monitoring site was $575 \mathrm{~mm}$. Two large rainstorms occurred during this period on 20-21 October and 18-19 November. Both storms occurred at the beginning of the rainy season when soil-moisture conditions where relatively dry. During the first storm, $74.4 \mathrm{~mm}$ of rain was recorded in $32 \mathrm{~h}$, and during the second storm $91 \mathrm{~mm}$ of rain fell in $29 \mathrm{~h}$. The two rainstorms were similar in magnitude and duration, but produced two different styles of infiltration. Both in the upper and lower parts of the slope, at depths greater than $120 \mathrm{~cm}$, the volumetric water content increased slowly, about 3\% in 3 days after the first storm, while it abruptly increased $4 \%$ in $33 \mathrm{~h}$ after the second storm. The collected pore-pressure data revealed that the hydraulic response was a transient process driven by rainfall (Fig. 3). The field monitoring site and data collected have been described in detail by Baum et al. (2005).

\section{Unsaturated hydraulic properties}

In transient flow the hydraulic head and the volumetric water content change as a function of time. The governing equation which describes the transient flow in a partially saturated soil is known as the Richards equation. In three dimensions, the Richards equation can be written as

$\frac{\partial \psi}{\partial t} \frac{\partial \theta}{\partial \psi}=\frac{\partial}{\partial x}\left[K(\psi) \frac{\partial h}{\partial x}\right]+\frac{\partial}{\partial y}\left[K(\psi) \frac{\partial h}{\partial y}\right]+\frac{\partial}{\partial z}\left[K(\psi) \frac{\partial h}{\partial z}\right]$,

where $\psi$ is the pressure head, $h$ is the hydraulic head (defined as $h=\psi+Z), K(\psi)$ is the pressure-dependent hydraulic con- ductivity, $\theta$ is the volumetric soil water content, $t$ is time, and $x, y, z$ are the spatial coordinates (Freeze and Cherry, 1979).

The non-linear relations that define the pressure-head dependence of the soil-moisture content and the hydraulic conductivity are called the Soil Water Characteristic Curve (SWCC) and the Hydraulic Conductivity Function (HCF), respectively. A widely used representation of the hydraulic characteristics of unsaturated soil is the equation formulated by Van Genuchten (1980):

$\theta(\psi)=\theta_{r}+\frac{\theta_{s}-\theta_{r}}{\left(1+|\alpha \psi|^{\beta}\right)^{1-1 / \beta}}$,

where $\theta_{s}$ is the saturated water content, $\theta_{r}$ is the residual moisture content, and $\alpha$ and $\beta$ are fitting parameters. This equation is often used in conjunction with the hydraulic conductivity function of Mualem (1976), which is expressed as follows:

$K(\psi)=K_{s} S_{e}^{0.5}\left[1-\left(1-S_{e}^{\beta /(\beta-1)}\right)^{1-1 / \beta}\right]^{2}$

where $S_{e}$ is the effective water content, defined as

$S_{e}=\frac{\theta-\theta_{r}}{\theta_{s}-\theta_{r}}$.

To solve a nonlinear equation like Eq. (1), a numerical model like the finite-element or the finite-difference method is needed. 
Table 1. Physical properties of the two kinds of soils at Edmonds as reconstructed in the laboratory.

\begin{tabular}{lll}
\hline & SOIL A & SOIL D \\
\hline Percentage Qva sand & 100 & 90 \\
Percentage Qlc silt & 0 & 10 \\
Average Porosity (calculated) $\mathrm{n}$ & 0.51 & 0.49 \\
Average density $\left(\mathrm{g} / \mathrm{cm}^{3}\right) \rho$ & 1.3 & 1.4 \\
Saturated Hydraulic Conductivity $(\mathrm{m} / \mathrm{s}) \mathrm{Ks}$ & $5 \times 10^{-5}$ & $1 \times 10^{-5}$ \\
Residual moisture content $\theta \mathrm{r}$ & 0.066 & 0.066 \\
Angle of Friction (degrees) $\phi$ & 33.6 & \\
Cohesion $(\mathrm{kPa}) \mathrm{c}^{\prime}$ & 4.33 & \\
\hline
\end{tabular}

\section{Methods}

The numerical modeling of infiltration processes is conducted with two codes: a 1-D finite-element code (HYDRUS 1-D; Simunek et al., 1998) and a 2-D finite-difference code (VS2DHI 3.0; Lappala et al., 1987). Both codes are computer programs for simulating water flow in variably saturated porous media. The mathematical model of these physical processes is developed by combining the law of conservation of fluid mass with the nonlinear form of Darcy's law (Richards equation). The numerical analysis is carried out using two one-dimensional models representative of the hillslope where the field instruments are installed (upper site and lower site); the 2-D modeling are then performed relying on the 1-D models. Field observations of pore-pressure response to rainfall collected at the Edmonds site are used to test model simulations.

\subsection{Numerical modeling of seepage processes}

The 1-D models are used to simulate the pore-pressure response in a single $7-\mathrm{m}$ thick surface layer. The model domain is divided into 5-cm-high rectangular elements. At the upper boundary, a time-dependent rainfall flux was applied $(q=R)$. According to field observation, the water table lies far below the domain of interest; to simulate this condition, a freely draining boundary (zero-gradient boundary condition) was applied at the bottom of the domain (Simunek et al., 1998); lateral boundary are considered as no-flux boundary (Fig. 4). Initial conditions are input as a pore-pressure field based on field measurements recorded prior to the rainfall event.

Hydraulic properties of the Edmonds hillslope material were determined using field and laboratory tests on the Advance Outwash Sand (here called soil $A$ ) and using laboratory tests on an artificial colluvium (here called soil $D$ ) made up of 10\% Lawton Clay and 90\% Advance Outwash Sand. Soil-water characteristic curves (SWCC) for the two materials were determined using capillary-rise tests (Godt, 2004). The saturated hydraulic conductivity values were determined in the field (soil $A$ ) using a Guelph constant-head permeameter (Elrick and Reynolds, 1992) and in the laboratory (soil $D$ )

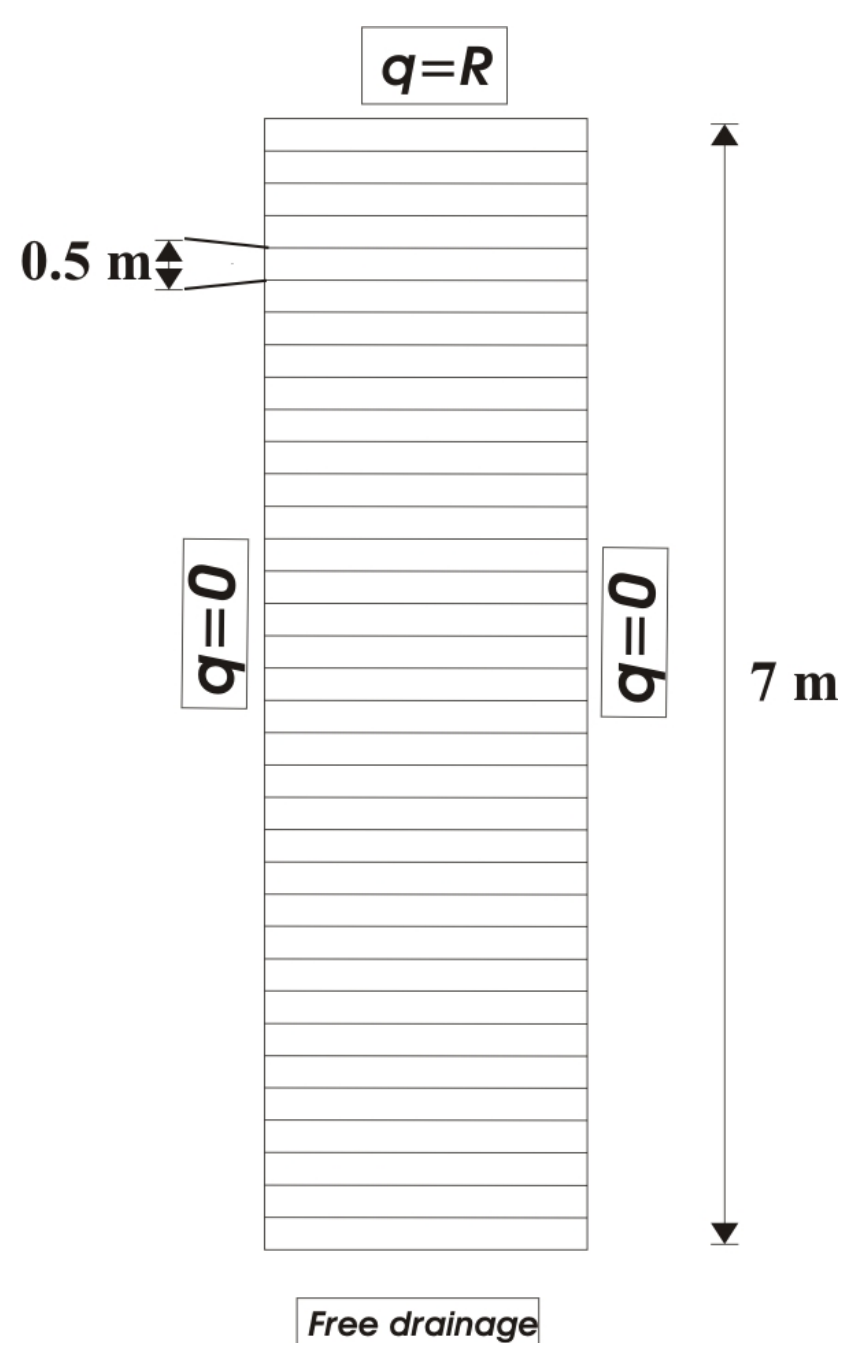

Fig. 4. Boundary conditions for the 1-D numerical modeling.

using constant-head tests. Laboratory and field testing has been described in additional detail by Godt (2004). We then estimate the $\alpha$ and $\beta$ parameters in Eqs. (2) and (3) using a least-squares fitting procedure in the computer code RETC 
Table 2. Input parameters of three soils investigated by numerical modeling.

\begin{tabular}{llll}
\hline & SOIL A & SOIL D & SOIL E \\
\hline$\theta_{s}$ & 0.3 & 0.29 & 0.30 \\
$\alpha$ & 8.5 & 8.68 & 6.50 \\
$\beta$ & 1.9 & 1.91 & 1.90 \\
$\mathrm{~K}_{S}(\mathrm{~m} / \mathrm{s})$ & $5 \times 10^{-5}$ & $1 \times 10^{-5}$ & $5 \times 10^{-5}$ \\
\hline
\end{tabular}

(Van Genuchten et al., 1991). Soil properties of the two materials are summarized in Table 1.

The laboratory soil-water characteristics determined in the laboratory are supplemented by monitoring observations of pressure head and volumetric moisture content collected during infiltration resulting from the rainfall on 18-19 November 2003. In general, the field water contents are greater for a given pressure head compared to those determined in the laboratory (Fig. 5); we attribute this to greater density and closer grain packing of the field soil. Even if there are not field data indicating nearly saturated conditions, the overall data suggested that the field saturated water content is smaller respect to lab estimation. The hypothetical soil having the field-lab estimate curve (which is obtained by adjusting the $\alpha$ and $\beta$ parameters in Eq. 2) is here called soil $E$ and is considered in the numerical simulations to reproduce the hydrologic response to measured rainfall at the Edmonds site. Values for the input parameters used for the model simulations are presented in Table 2.

Two-dimensional modeling is performed based on the results of the 1-D simulations. Considering both the horizontal $(x)$ and the vertical $(z)$ directions, the 2-D numerical modeling allows investigation of the lateral component of the subsurface flux and the influence of a contrast in hydraulic properties on the formation of a perched water table. A layered system with a slope-parallel contact $1 \mathrm{~m}$ below the ground surface was discretized into $5 \mathrm{~cm}$-square cells. The lateral boundaries of the 2-D domain are prescribed as noflow boundaries and the flow is allowed to drain at the base toward a seepage face. Initial conditions are input as a porepressure field taken from field observations before the rainfall event recorded by the two tensiometer nests; this field is extended to the other parts of the model domain. As from lab tests (Godt, 2004) decreasing porosity has been noticed from both downslope and with depth, the model takes into account physical and hydraulic properties of soils $A$ and $D$.

\subsection{Sensitivity analysis}

Numerical modeling can be used to investigate how the hydraulic response of the slope changes as a function of soil properties, layering effects and boundary conditions. In order to investigate how variations in texture, porosity and grain size affect the hydraulic conditions and hence the stability of the slope, we apply the same numerical approach to different soil properties and to different rainfall rates.

\subsubsection{One-layer-system sensitivity analysis}

The sensitivity analysis is implemented with a single 1-m deep layer with a freely draining lower boundary and initially uniform soil-moisture conditions of $15 \%$ based on monitoring data collected before the 18-19 November 2003 rainfall (Baum et al., 2005). The numerical approach is applied to the properties of the Advance Outwash Sand (soil A), the experimental soil $D$ determined from the capillary-rise tests, and the properties determined from the field measurements of pressure head and moisture content (soil E). Hydraulic properties of each of the soils are summarized in Table 2. A constant rainfall flux ranging from 1 to $10 \mathrm{~mm} / \mathrm{hr}$ is simulated for a duration of $15 \mathrm{~h}$. The influence of the saturated hydraulic conductivity, $K_{S}$, on the pressure head response was examined by varying the value of $K_{S}$ by a factor of 4 (from half to twice the investigated value).

\subsubsection{Two-layer-system sensitivity analysis}

A further examination of the influence of the saturated hydraulic conductivity is undertaken to investigate the hydrologic conditions that may cause slope instability. The analysis is implemented with a two-layer-system, by holding constant the values of the saturated conductivity of the upper layer, $K_{S(1)}\left(5 \times 10^{-5} \mathrm{~m} / \mathrm{s}\right)$, and of $q$ equal to rainfall rate $R$, and varying the value of the saturated conductivity of the lower layer, $K_{S(2)}$. The rainfall rate, $R$, is $10 \mathrm{~mm} / \mathrm{hr}$, which is typical of heavy rainfall in the Edmonds area.

\subsection{Numerical modeling for examining mitigation mea-} sures

In order to quantify the change in the hydraulic response caused by a drainage system, we first implement a 2-D model that represents the hydraulic response of the slope without the drainage system. This analysis is the same as described in the two-layer-system sensitivity analysis section, extended from one dimension to two dimensions. The model domain considers a central portion of the slope that is about $20 \mathrm{~m}$ long and $10 \mathrm{~m}$ deep. The upslope lateral boundary condition is a no-flux boundary $(q=0)$, as the previous simulations confirmed that the upslope flow is negligible. The downslope lateral boundary condition and the basal boundary are no-flux boundaries $25 \mathrm{~m}$ down to the slope and 40 $\mathrm{m}$ below the ground surface (Fig. 11a). For initial conditions, we investigate both the case of non-equilibrium initial pressure head taken from the field monitoring data before the 18-19 November 2003 rainfall event, and a general case of slope-parallel flow with a water table $0.5 \mathrm{~m}$ beneath the ground surface (Fig. 12a). In order to simulate slope-parallel flow, the side boundaries are specified as flux boundaries that 


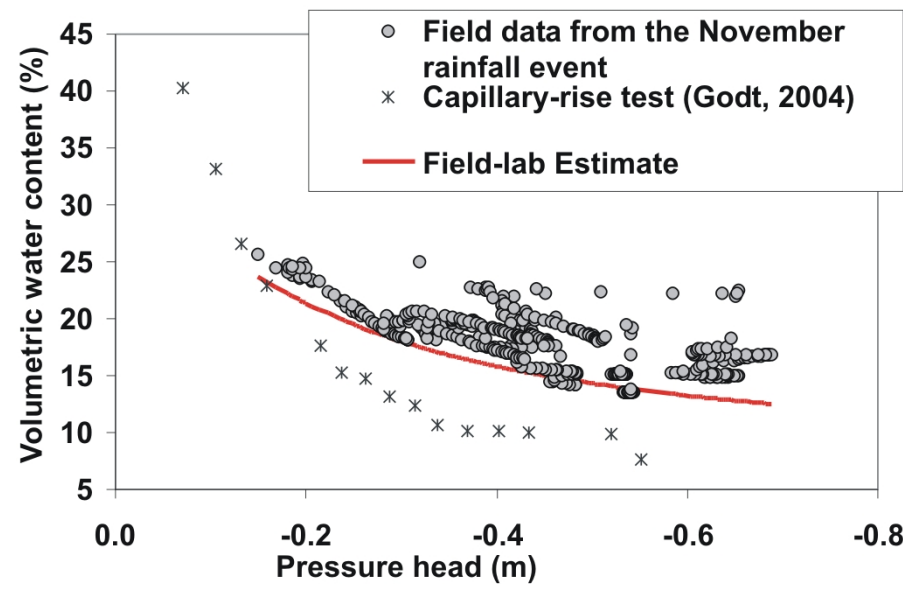

Fig. 5. Comparison between soil-moisture and pore-pressure data collected from the field during the 18-19 November event and the results from the capillary test on soil A.

\section{$0.2 \mathrm{~m}$ depth}

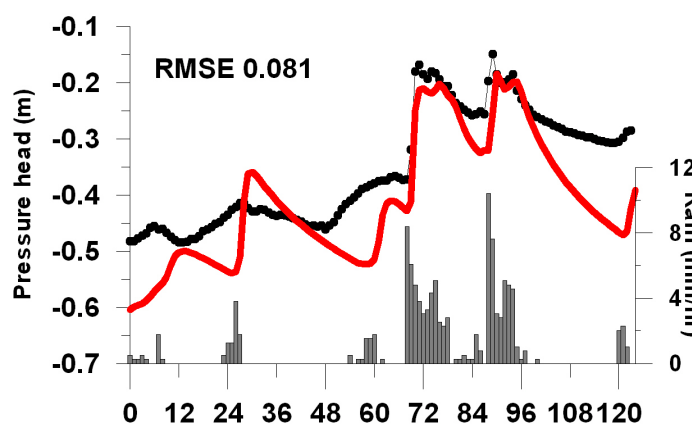

15-Nov-03 16-Nov-03 17-Nov-03 18-Nov-03 19-Nov-03 20-Nov-03

Elapsed time (hr)

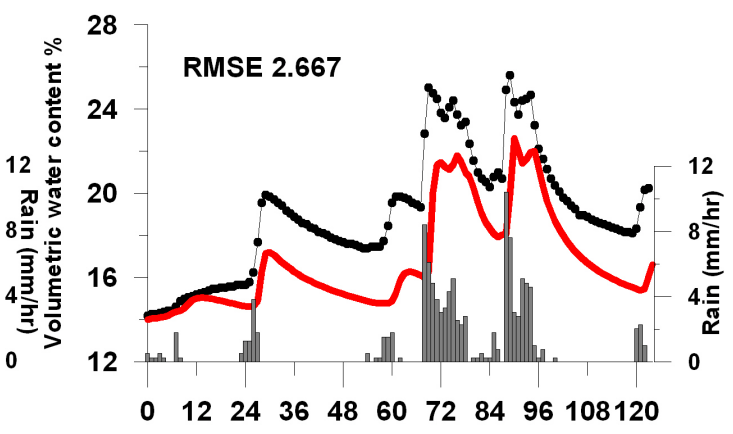

15-Nov-03 16-Nov-03 17-Nov-03 18-Nov-03 19-Nov-03 20-Nov-03

Elapsed time (hr)

\section{$1 \mathrm{~m}$ depth}

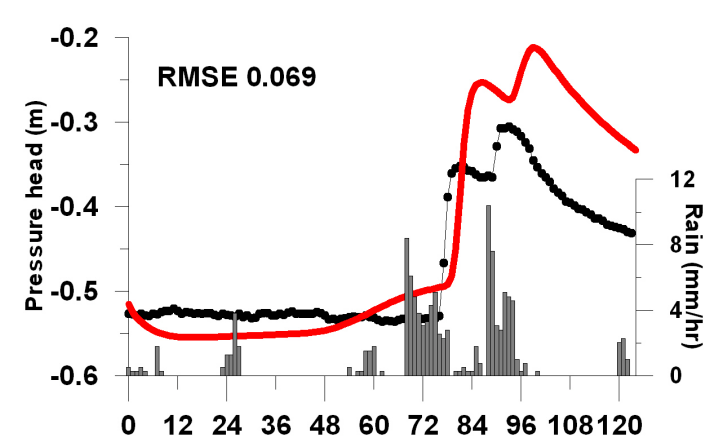

15-Nov-03 16-Nov-03 17 -Nov-03 18-Nov-03 19-Nov-03 20-Nov-03

Elapsed time (hr)

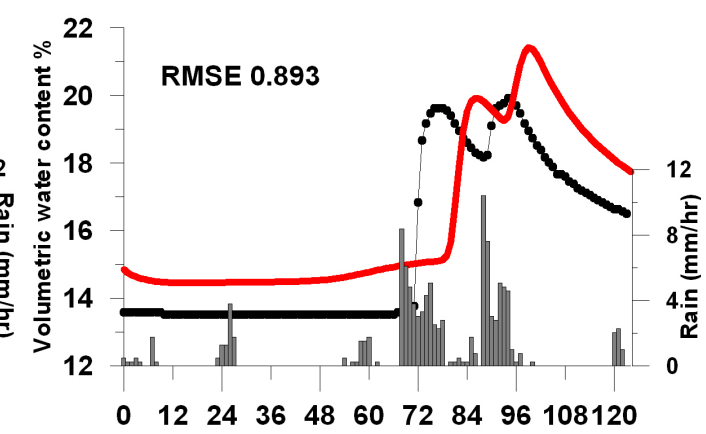

15-Nov-03 16-Nov-03 17-Nov-03 18-Nov-03 19-Nov-03 20-Nov-03

Elapsed time (hr)

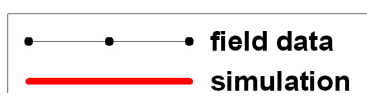

Fig. 6. Results of numerical simulations of pore-water pressure and volumetric water content compared with field data (RMSE=Root Mean Squared Error). Vertical bars indicate hourly rainfall. 


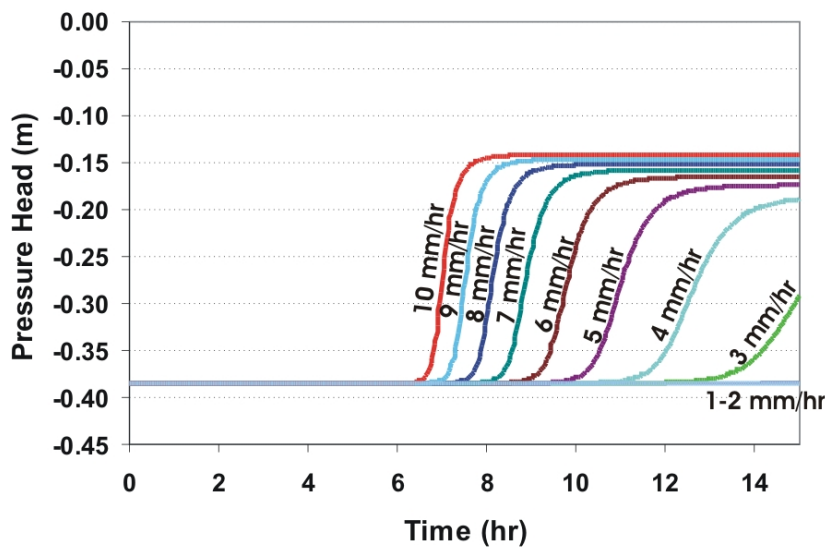

Fig. 7. Time versus pressure-head variation at 1-m depth in relation to different rainfall rates for soil $A$.

add and subtract water upslope and downslope, respectively. The same 2-D models are then modified by assuming the presence of a simple drainage system $0.5 \mathrm{~m}$ wide and $1 \mathrm{~m}$ deep located perpendicular to the slope. As the dewatering process is only possible when the pore pressure is positive, a drainage system can be represented with a seepage-face boundary (Figs. 11b and 12b). Thus, keeping the same model domain, model boundary and initial conditions, soil properties, rainfall rate and duration, it is possible to examine the direct effects of the drainage system on the hydrologic response. The analysis implemented with the non-equilibrium initial condition is called Model $A$; the analysis implemented with the slope-parallel flow is called Model $B$, respectively. In the next section we describe the comparison of the numerical modeling results with the field monitoring observations.

\section{Results}

7.1 Comparison of numerical simulations with field monitoring data

The average depth of the failure surface of shallow landslides on the hillsides along Puget Sound in the Edmonds area is about $1.6 \mathrm{~m}$ (Baum et al., 2000), and we have focused our model simulations at that depth. Both pore pressure and moisture content modeled with VS2DH and HYDRUS using the soil $E$ parameters and the 1-D model domain described above (Fig. 6) reasonably reproduce the field monitoring data. The modeled pore-pressure peak response at $0.2 \mathrm{~m}$ depth matches quite well with monitoring observations. At $1 \mathrm{~m}$ depth the simulated peak response is about $0.1 \mathrm{~m}$ greater than monitoring observations and the simulated moisture contents at both depths are slightly underestimated. Similar comparisons were obtained from the 2-D model using the same material properties and boundary conditions.

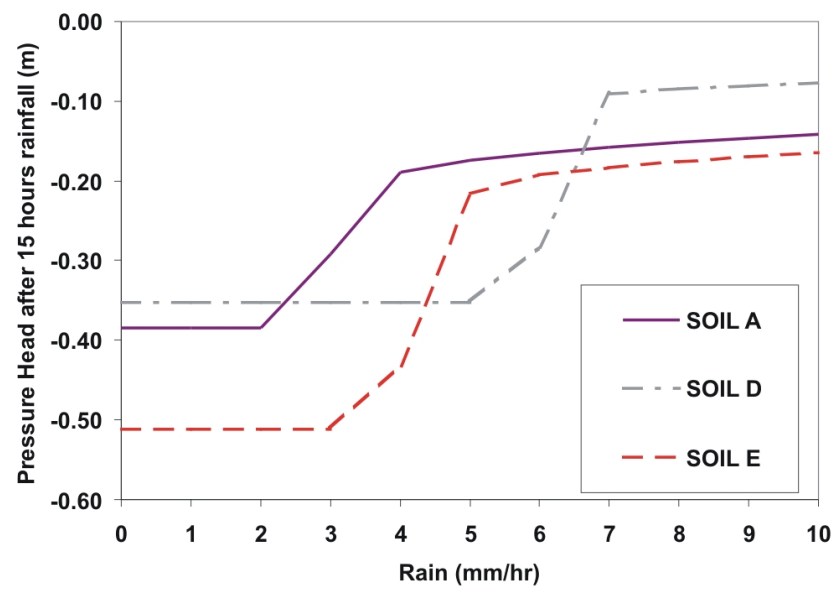

Fig. 8. Change in pressure-head at $1-\mathrm{m}$ depth after $15 \mathrm{~h}$ at different rainfall rates for the three different soils.

\subsection{Sensitivity analysis}

\subsubsection{One-layer-system sensitivity analysis}

In this section we examine the sensitivity of the pressurehead response at $1-\mathrm{m}$ depth to rainfall rate and variation of the saturated hydraulic conductivity. Fig. 7 shows pressure head at $1 \mathrm{~m}$ below the ground surface in a 1-D profile with the hydraulic properties of soil $A$ (Table 2) as a function of time for a range of constant rainfall rates. For soil $A$, rainfall with a rate of less than $2 \mathrm{~mm} / \mathrm{hr}$, produces no change in pressure head at $1 \mathrm{~m}$ depth after $15 \mathrm{~h}$ of flux at the surface. In general, greater rainfall rates produce a greater pressurehead response in a shorter time. The non-linear effects of the hydraulic conductivity function are shown in the abrupt increase in the maximum pressure head with increasing rainfall rate (Fig. 8). For example, for soil $E$, the maximum pressure head at $1-\mathrm{m}$ depth after $15 \mathrm{~h}$ of $4 \mathrm{~mm} / \mathrm{hr}$ rainfall is about $-0.45 \mathrm{~m}$; increasing the rainfall rate by only $1 \mathrm{~mm} / \mathrm{hr}$ to $5 \mathrm{~mm} / \mathrm{hr}$ increases the maximum pressure head to $-0.18 \mathrm{~m}$ after $15 \mathrm{~h}$. Additional rainfall rate increases up to $10 \mathrm{~mm} / \mathrm{hr}$ only increase the maximum pressure head to about $-0.22 \mathrm{~m}$. Results of the variation of saturated hydraulic conductivity are shown in Fig. 9 for soil $A, D$ and $E$ as the pressure head after $15 \mathrm{~h}$ of constant rainfall flux at $1 \mathrm{~m}$ depth. For soils $A$ and $E$, if $K_{S}$ is twice or half the original value, the maximum pressure head at $1-\mathrm{m}$ depth after $15 \mathrm{~h}$ of a $10 \mathrm{~mm} / \mathrm{hr}$ intensity rainfall varies less than $0.04 \mathrm{~m}$. The maximum pressure head for lower rainfall rates is higher for higher values of $K_{S}$ for the three soils, but when the rainfall rate increases, the trend is inverted. In the next section, we describe the sensitivity of the two-layer model to the magnitude of the contrast in hydraulic conductivity between the two layers. 

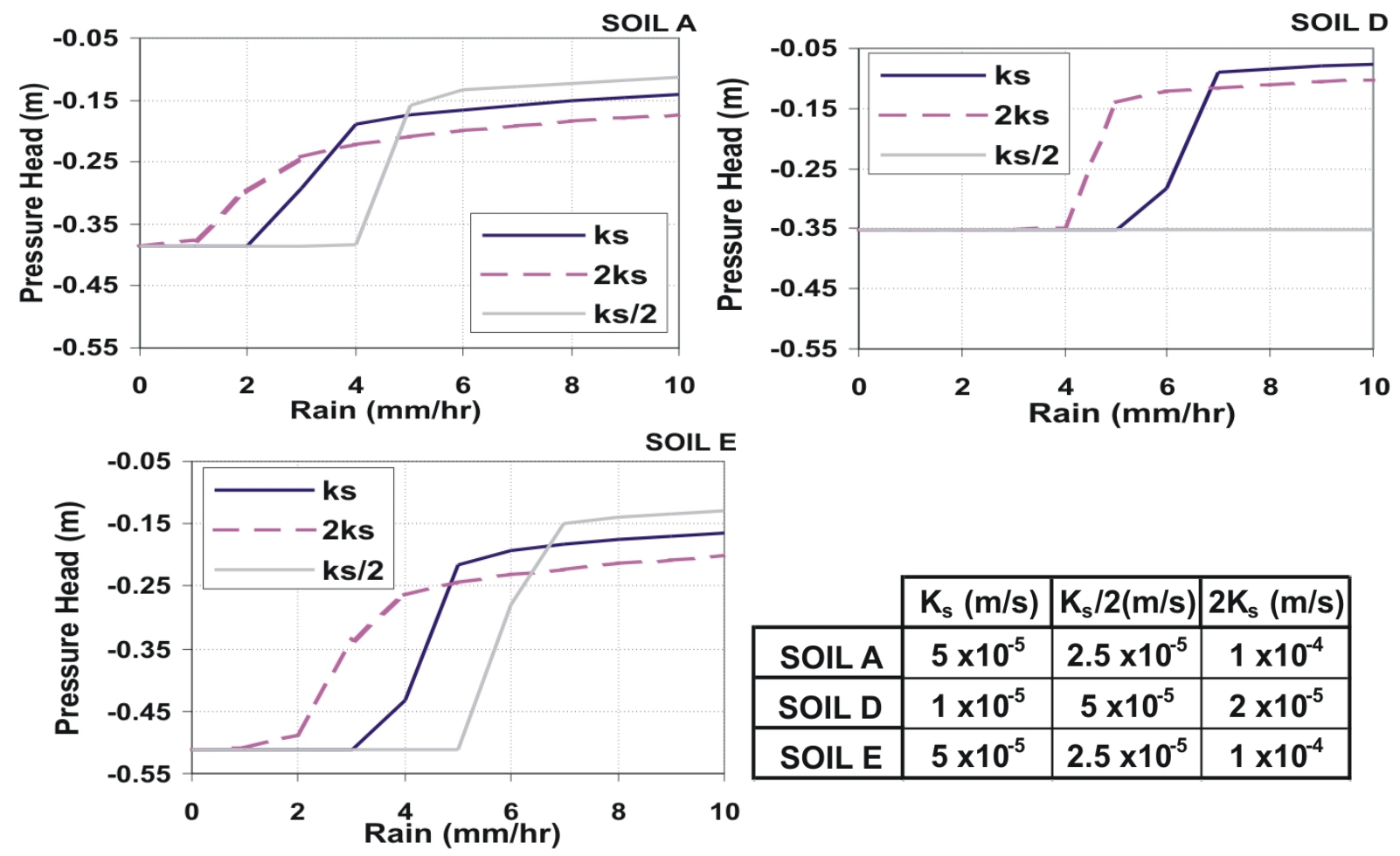

\begin{tabular}{|c|c|c|c|}
\cline { 2 - 4 } \multicolumn{1}{c|}{} & $\mathrm{K}_{\mathrm{s}}(\mathrm{m} / \mathrm{s})$ & $\mathrm{K}_{\mathrm{s}} / 2(\mathrm{~m} / \mathrm{s})$ & $2 \mathrm{~K}_{\mathrm{s}}(\mathrm{m} / \mathrm{s})$ \\
\hline SOIL A & $5 \times 10^{-5}$ & $2.5 \times 10^{-5}$ & $1 \times 10^{-4}$ \\
\hline SOIL D & $1 \times 10^{-5}$ & $5 \times 10^{-5}$ & $2 \times 10^{-5}$ \\
\hline SOIL E & $5 \times 10^{-5}$ & $2.5 \times 10^{-5}$ & $1 \times 10^{-4}$ \\
\hline
\end{tabular}

Fig. 9. Pore pressure change at 1-m depth in relation to the variation of the saturated hydraulic conductivity for each soil.

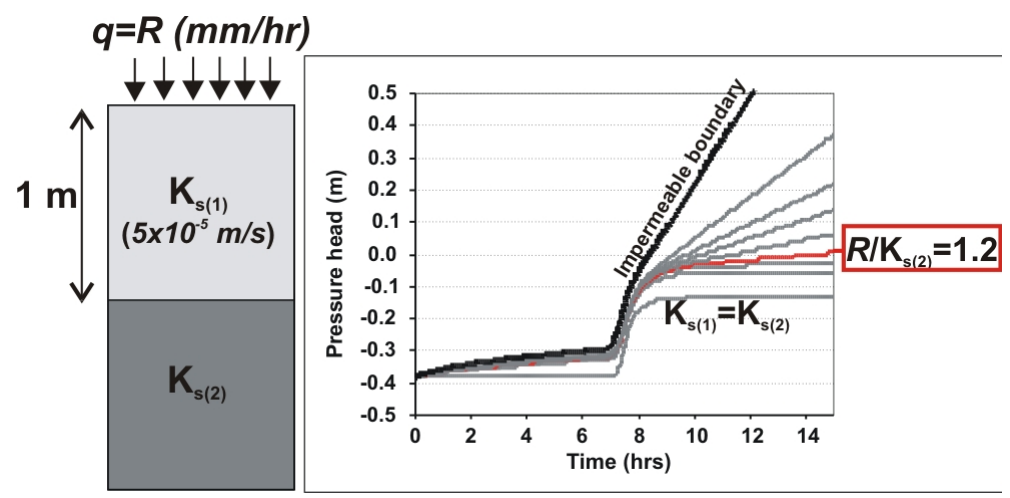

Fig. 10. Pore pressure response with time in relation to the changing ratios of $R / K_{S(2)}$ and $K_{S(1)} / K_{S}(2)$.

\subsubsection{Two-layer-system sensitivity analysis}

We begin the examination of the response of a two-layersystem (Fig. 10) with a homogeneous soil (soil $A$ ) where the saturated hydraulic conductivity of the upper layer, $K_{S(1)}$, is the same as the saturated conductivity of the lower layer, $K_{S(2)}$. The upper boundary is again a prescribed constant flux and the lower boundary is allowed to drain freely. The hydraulic response is identical to that from previous analysis for $10 \mathrm{~mm} / \mathrm{hr}$ rainfall (Fig. 7). If $K_{S(2)}$ is decreased to less than that of $K_{S(1)}$, the pressure head at the contact between the two layers at $1-\mathrm{m}$ depth continues to increase after the arrival of the wetting front after about $7 \mathrm{~h}$ (Fig. 10). If the rainfall rate exceeds the saturated hydraulic conductivity of the lower layer, a saturated zone or a perched water table begins to form after about $15 \mathrm{~h}$ of rainfall. Figure 10 shows the case where $R / K_{S(2)}$ is 1.2 and the pressure head after $15 \mathrm{~h}$ is about $0.2 \mathrm{~m}$. For the limiting case with an impermeable lower boundary at $1-\mathrm{m}$ depth, the head at $1-\mathrm{m}$ depth is greater than $0.5 \mathrm{~m}$ after just $12 \mathrm{~h}$ of rainfall. In the following section, we describe a two-dimensional modeling example and show the effects of a trench drain on a transient and a perched saturated zone. 
(a)

\section{INITIAL CONDITIONS}

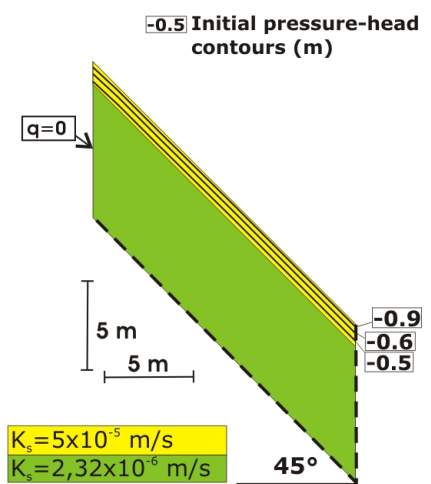

(b)

INITIAL CONDITIONS

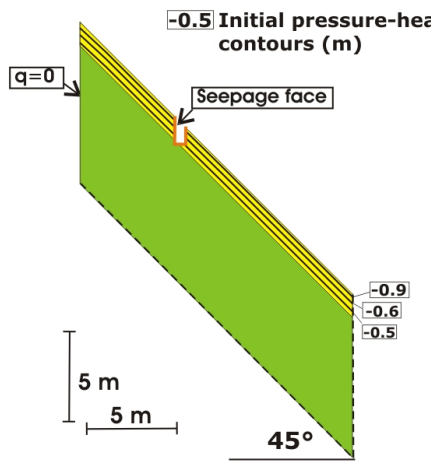

Fig. 11. Comparison between pressure heads without a drain (a) and with a drain (b) if strongly unsaturated soil initial conditions are considered (Model $A$ ).

7.3 Numerical modeling for investigating the efficiency of mitigation measures

We extended the analysis of the two-layer-system to two dimensions to examine the effects of a drainage system on a steep hillslope (Fig. 11). The model domain is a two layer-system of soil $A$ overlying soil $D$, described earlier in Sect. 6.3. We applied a rainfall rate that is greater than the saturated hydraulic conductivity of the lower layer $\left(R / K_{S(2)}=1.2\right.$, where $R=10 \mathrm{~mm} / \mathrm{hr}$, and which corresponds to a $K_{S(1)} / K_{S(2)}$ ratio of 22$)$.

For an initially unsaturated slope with a pressure-head profile decreasing from $-0.5 \mathrm{~m}$ at the contact between the two materials to $-0.9 \mathrm{~m}$ near the ground surface (Model $A$ ) without drainage, a perched saturated zone $1.7 \mathrm{~m}$ thick forms after about $10 \mathrm{~h}$ of rainfall (Fig. 11a). The addition of a trench drain decreases the pore-pressure response both upslope and downslope of the drain by $0.1 \mathrm{~m}$, although a perched water table $0.5 \mathrm{~m}$ thick still forms (Fig. 11b). For a slope with a shallow initial water table $0.5 \mathrm{~m}$ above the contact and slope parallel flow (Model $B$ ), the effect of a trench drain is greater (a)
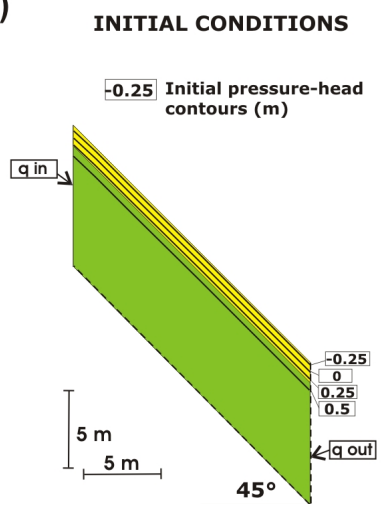

(b)

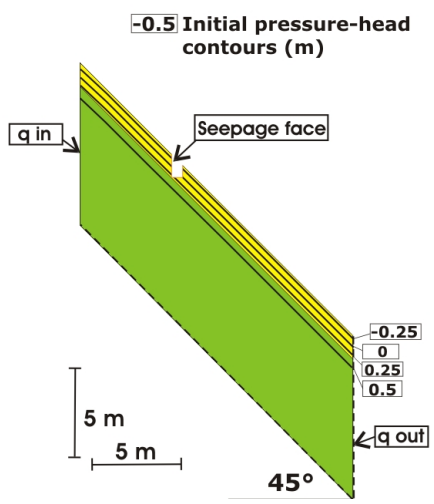

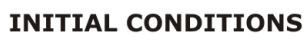

SIMULATION

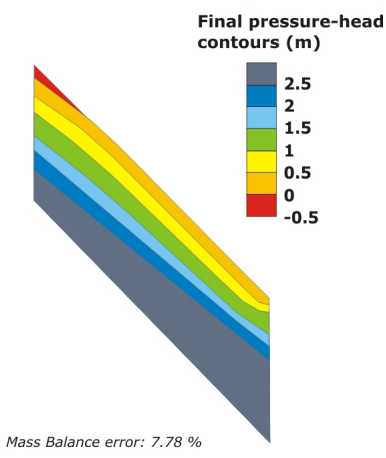

SIMULATION

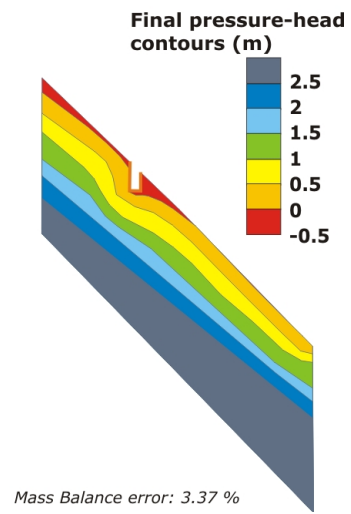

Fig. 12. Comparison between pressure heads without a drain (a) and with a drain (b) if a near-surface water table as the initial condition is considered (Model $B$ ).

(Fig. 12). In both cases (without and with the drain) there is not development of a perched water table as in Model $A$; as a matter of fact, the water table becomes shallower in comparison to the initial conditions. The presence of a trench drain abruptly decreases the pore pressure in the vicinity of the drain, mostly downslope from it.

To quantify the effect of a trench drain for both Models $A$ and $B$, the simulated pressure-head data are plotted at various times during the rainfall event along the slope at 1-m depth without the drain $(H z)$ and with the drain $(H)$ (Figs. 13 and 14). For Model $A$, the pressure head changes little before $4 \mathrm{~h}$ of rainfall, and only after $10 \mathrm{~h}$ of rainfall does it decreases from an average value of $0.1 \mathrm{~m}$ to an average value of $0.05 \mathrm{~m}$ for most of the slope. Only an abrupt decrease (from 0.1 to $-0.2 \mathrm{~m}$ ) occurs in the upper part of the slope. In contrast, Model $B$ shows an abrupt change in pressure head between $2 \mathrm{~m}$ upslope and $6 \mathrm{~m}$ downslope from the drain for almost the entire duration of the rainfall event; after $10 \mathrm{~h}$ the pressure head is as much as $0.6 \mathrm{~m}$ less than that simulated without the trench drain. 

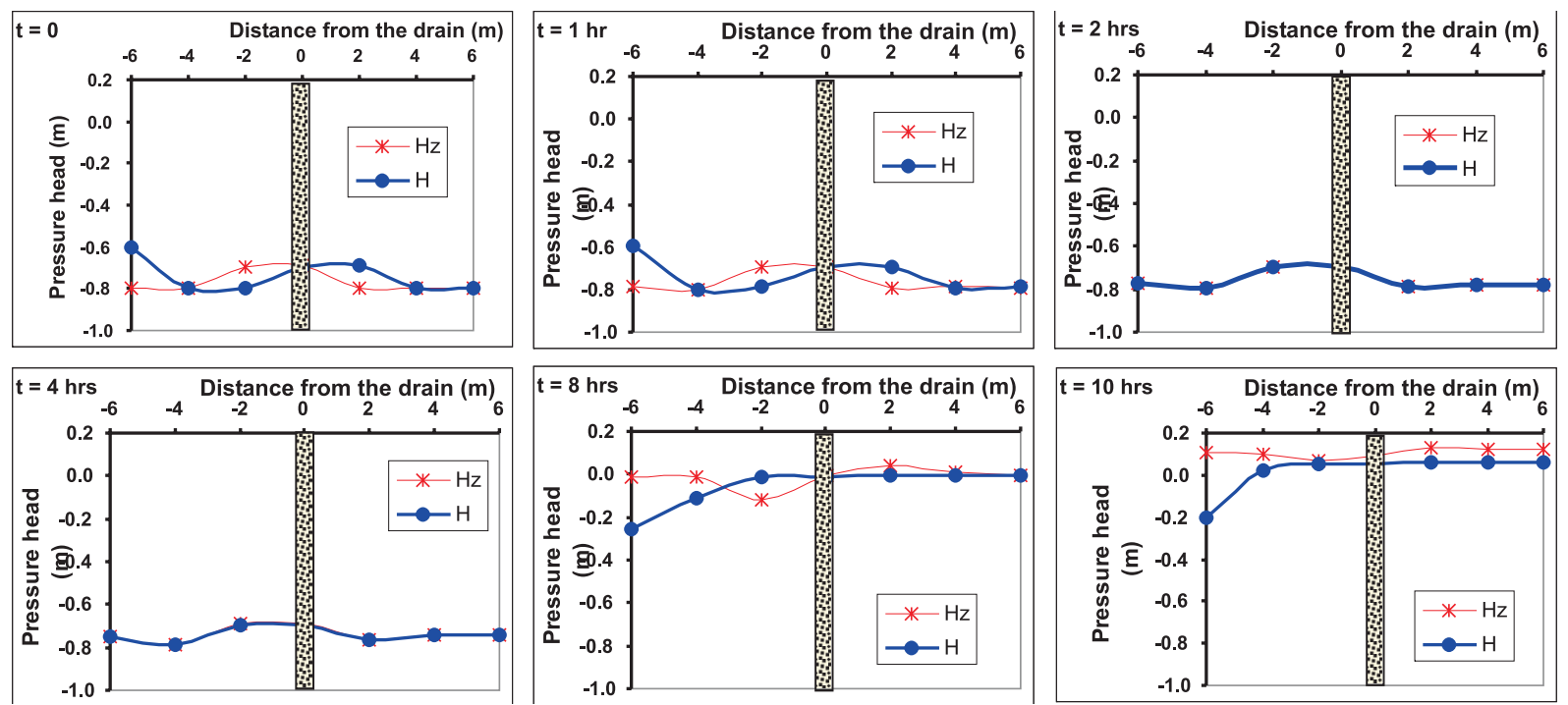

Fig. 13. Pore-pressure values for Model $A$ at 1-m depth along the slope during the drain simulation. Hz: pore-pressure values if no drains are installed; $\mathrm{H}$ : pore-pressure values if one drain is installed (distance has positive value downslope and negative value upslope with respect to the drain).
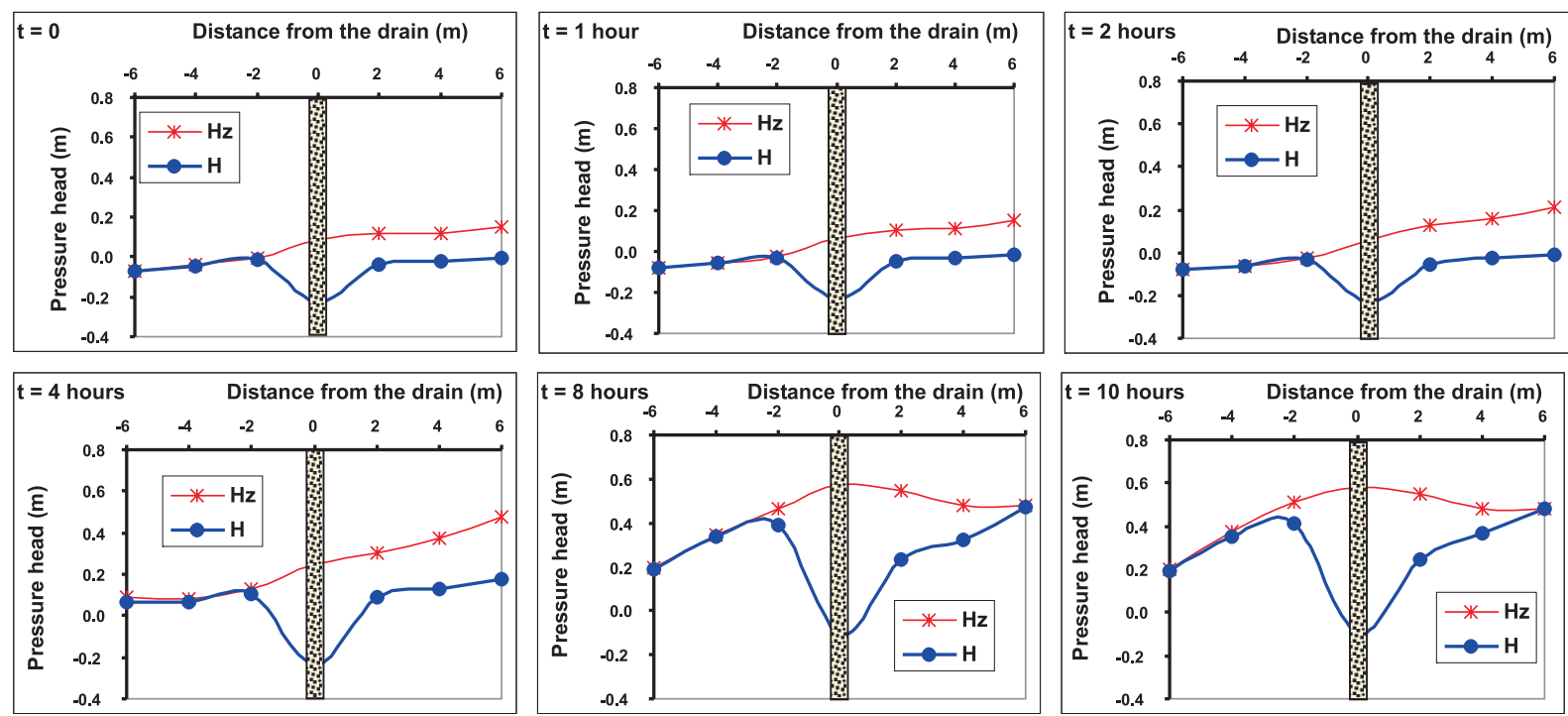

Fig. 14. Pore-pressure values for Model $B$ at $1-\mathrm{m}$ depth along the slope during the drain simulation. Hz: pore-pressure values if no drains are installed; $\mathrm{H}$ : pore-pressure values if one drain is installed (distance has positive value downslope and negative value upslope with respect to the drain).

\section{Discussion}

Field measurements of both pressure-head and moisturecontent response to infiltration on a steep hillslope can be reasonably reproduced using 1- and 2-D numerical models and material hydraulic properties measured in the laboratory and in the field. The models tend to overestimate the peak pressure-head response by about $10 \mathrm{~cm}$ with respect to the field data. This was not observed for the soil-moisture data, indicating that the Soil Water Characteristic Curve and the Hydraulic Conductivity Function used in the simulations may be more non-linear than the hydraulic characteristic of the in situ soil. The differences in the shapes of the Soil Water Characteristic Curve and Hydraulic Conductivity Function may result from small differences in the porosity and density of the in situ soil and the values used for the model input. The overall results of the numerical modeling suggest that, in general, the in situ soil has a greater density and thus a smaller porosity as compared to the soil (Qva) tested in the laboratory. 
Results of the sensitivity analysis on the role of the hydraulic conductivity in a one-layer-system reveal that the pressure-head response depends in part on the saturated hydraulic conductivity value even if the material is unsaturated. The two-layer sensitivity analysis of the hydraulic conductivity highlights the influence of the saturated conductivity of the lower layer with respect to the rainfall rate. If the rainfall rate exceeds $K_{S}$ of the lower layer for an appreciable amount of time even in an initially unsaturated slope, a perched water table may form and the slope may destabilize. If the rainfall rate is much smaller than the saturated conductivity of the upper layer, the formation of a perched water table is controlled by the ratio of the rainfall rate to the saturated conductivity of the lower layer. The rate of pore-pressure increase in the saturated zone at the contact between the two layers is influenced by the hydraulic conductivity function of the overlying soil. For the soil properties and rainfall rate typical of the Edmonds field site, a ratio of rainfall rate to hydraulic conductivity of 1.2 allows the formation of a perched water table to occur after $15 \mathrm{~h}$ of rainfall at $1-\mathrm{m}$ depth. For the measured $K_{S}$ of the hillslope material at the field site $\left(5 \times 10^{-5} \mathrm{~m} / \mathrm{s}\right)$ and $10 \mathrm{~mm} / \mathrm{hr}$ rainfall rate, this ratio corresponds to a contrast in the saturated hydraulic conductivity of the two layers of slightly more than an order of magnitude. Thus, large contrasts in soil properties are likely not needed for a perched saturated zone to transiently form at the base of loose residual soil or colluvium during heavy rainfall.

The investigation of the effect of a drainage system on potential instability was only possible after our examination of the transient effects of infiltration on the conditions likely to lead to slope failure (formation of a perched saturated zone). The results of the sensitivity analyses show the dependence on material properties of the transient subsurface response to rainfall and their subsequent effect on mitigation measures. If slope-parallel flow and a shallow water table are assumed as initial conditions (Model $B$ ), the effect of a drainage system could be overestimated. In Model $A$, the strong unsaturated properties that persist during the first $8 \mathrm{~h}$ of the simulated rainfall event are the cause of the null effect of the drainage system during that period of time, as no flow passes that boundary unless it is saturated. However, as soon as a perched water table can build up, the presence of the drain influences the slope parallel flow that characterizes the last few hours of the rainfall event.

This analysis of the effect of drains on the near-subsurface hydrologic response of hillside soils during a rainfall event is a step in the more complete examination of the effects of infiltration on the transient stability of hillslopes. These preliminary results clarify how the engineering works and hydrologic conditions of the slope interact for two initial conditions. Worst-case scenarios (i.e., water table at the ground surface and slope-parallel flow) are often assumed for engineering design purposes; however, at the Edmonds site, a persistent water table has not been observed at typical shallow landslide depths. For field settings such as the Edmonds site, we suggest that results from transient analysis using numerical solutions to variably-saturated flow can provide insight into landslide processes and engineering structures that may mitigate landslide occurrence.

\section{Conclusions}

We have demonstrated that numerical modeling of variablysaturated flow in one and two dimensions can reproduce pressure-head and moisture-content data collected during infiltration on a steep coastal bluff prone to landslide activity. These numerical tools were used to show how the effects of variation in physical and hydraulic properties of surficial hillside soils can influence the infiltration process. Results from these numerical simulations were then used to examine the effects of a trench drain on potentially destabilizing porepressure conditions. Variation of the saturated hydraulic conductivity by a factor of 4 shows that the hydraulic response is influenced not only by the shape of the hydraulic conductivity function but also by the value of saturated hydraulic conductivity even if the flow takes place in an unsaturated soil. The development of a perched water table in a two-layersystem of soils typical of the field site at Edmonds, Washington, is controlled by the ratio of the rate of rainfall, $R$, to the saturated conductivity of the lower layer, $K_{S(2)}$. Potentially destabilizing pore-pressure conditions result even when the ratio of $R / K_{S(2)}$ is as small as 1.2 .

Results from the field comparison and the sensitivity analyses were used to investigate the effects of a drainage system on the near-surface hydrologic response of the hillslope and, hence, on slope stability. The results are influenced by the assumed initial conditions: if a traditional approach in designing mitigation measures with a slope-parallel flow and a shallow water table is considered, the effects of drains can be overestimated according to the results obtained considering the observed variably saturated initial conditions.

Acknowledgements. The authors would like to express their gratitude to R. L. Baum, U.S. Geological Survey. We would like to acknowledge for the indispensable field and laboratory data that were used in this paper. Without this data it would have been impossible to complete this study. The authors also thank the staff of the U.S. Geological Survey Landslide Hazard program for supporting the research and for assisting in evaluating this paper.

Edited by: M. Arattano

Reviewed by: G. Wieczorek 


\section{References}

Anderson, M. G. and Howes, S.: Development and application of a combined soil water-slope stability model, Quart. J. Eng. Geology, 18, 225-236, 1985.

Baum, R. L., Chleborad, A. F., and Schuster, R. L.: Landslides triggered by the winter 1996-97 storms in the Puget Lowland, Washington, U.S. Geological Survey Open-File Report, 98-239, 1998.

Baum, R. L., Harp, E. L., and Hultman, W. A.: Map showing recent and historic landslide activity on coastal bluffs of Puget Sound between Shilshole Bay and Everett, Washington, U.S. Geological Survey Miscellaneous Field Studies Map MF-2346, 2000.

Baum, R. L., McKenna, J. P., Godt, J. W., Harp, E. L., and McMullen, S. R.: Hydrologic monitoring of landslide-prone coastal bluffs near Edmonds and Everett, Washington, 20012004, U.S. Geological Survey Open-File Report 2005-1063, http://pubs.usgs.gov/of/2005/1063/, 2005.

Baum, R. L., Savage, W. Z., and Godt R. W.: TRIGRS - A Fortran Program for Transient Rainfall Infiltration and Grid-Based Regional Slope-Stability Analysis, U.S. Geological Survey OpenFile Report, 2002-424, http://pubs.usgs.gov/of/2002/424/, 2002.

Brooks, D.: Where floods did their most damage to trails, forest roads, The Seattle Times, 19 November 2003.

Brooks, S. M. and Richards, K. S.: The significance of rainstorm variations to shallow translational hillslope failure, Earth Surface Processes and Landforms, 19(1), 85-94, 1994.

Church, P. E.: Some precipitation characteristic of Seattle, Weatherwise, December, 244-251, 1974.

Coe, J. A., Michael, J. A., Crovellin, R. A., Savage, W. Z., Laprade, W. T., and Nashem, W. D.: Probabilistic assessement of precipitation-triggered landslides using historical records of landslide occurrence, Environ. Eng. Geosci., 10(2), 103-122, 2004.

Elrick, D. E. and Reynolds, W. D.: Infiltration from constant-head well permeameters and infiltrometers, in: Advances in Measurement of Soil Physical Properties: Bringing Theory into Practice, edited by: Topp, G. C., Reynolds, W. D., and Green, R. E., Madison, Wisconsin, Soil Sci. Soc. Amer. Proc., 1-24, 1992.

Forbes, H.: Landslide investigation and correction, Amer. Soc. Civil Eng. Trans., 112, 377-442, 1947.

Freeze, R. A. and Cherry, J. A.: Groundwater, Prentice-Hall, Englewood Cliffs, New Jersey, 1979.

Galster, R. W. and Laprade, W. T.: Geology of the Seattle Quadrangle, Washington, United States of America, Bull. Assoc. Eng. Geologists, 18(3), 235-302, 1991.

Gerstel, W. J.: The upside of the landslides of February 1996: validating a stability analysis of the Capitol Campus Bluffs, Olympia Washington, Washington Geology, 24(3), 3-16, 1996.

Godt, J. W.: Observed and modelled rainfall conditions for shallow landsliding in the Seattle, Washington, area, $\mathrm{PhD}$ Thesis, University of Colorado, 2004.

Godt, J .W., Baum., R. L., and Chleborad, A. F.: Rainfall characteristics for shallow landsliding in Seattle, Washington, USA, Earth Surface Processes and Landforms, 31(1), 97-110, 2006.
Harrell, D. C. and Craft, M.: Record rain wallops region, Seattle Post-Intelligencer, 19 November 2003.

Hutchinson, J. N.: Assessment of the effectiveness of corrective methods in relation to geological conditions and types of slope movements, Bull. Int. Assoc. Eng. Geology, 16, 131-155, 1977.

Iverson, R. M.: Landslide triggering by rain infiltration, Water Resour. Res., 36(7), 1897-1910, 2000.

Lappala, E. J., Healy, R. W., and Weeks, E. P.: Documentation of computer program VS2D to solve the equations of fluid flow in variably saturated porous media, U.S. Geological Survey Water Resour. Investigation Report, 1987.

Miller, D. J.: Damage in King County from the storm of 9 January 1990, Washington Geology, 19, 28-37, 1991.

Mualem, Y.: A new model for predicting the hydraulic conductivity of unsaturated porous media, Water Resour. Res., 12(3), 513522, 1976.

Porter, S. C. and Swanson, T. W.: Radiocarbon age constraints on rates of advance and retreat of the Puget Lobe of the Cordilleran Ice Sheet during the last glaciation, Quat. Res., 50, 205-213, 1998.

Reid, M. E., Nielsen, H. P., and Driess, S. J.: Hydrologic factors triggering a shallow hillslope failure, Bull. Assoc. Eng. Geologists, 25(3), 349-361, 1988.

Simunek, J., Huang, K., and van Genuchten, M. T.: The HYDRUS Code for Simulating the Movement of Water, Heat, and Multiple Solutes in Variably Saturated Media, Version 6.0, Research Report No. 144, U.S. Salinity Laboratory, U.S. Department of Agriculture, Agric. Res. Service, Riverside, California, 1998.

Snyder, D. E., Gale, P. S., and Pringle, R. F.: Soil Survey of King County area, Washington, U.S. Department of Agriculture, Soil Conservation Service, 1973.

Thorsen, G. W.: Landslide provinces in Washington, in: Engineering Geology in Washington, edited by: Galster, R. W., Washington Division of Geology and Earth Resour. Bull., 78(1), 71-89, 1989.

Troost, K. G., Booth, D. B., Wisher, A. P., and Shimel, S. A.: The geologic map of Seattle - A progress report, 2005, U.S. Geological Survey Openfile report 2005-1252, scale 1:24000, http://pubs.usgs.gov/of/2005/1252/, 2005.

Tubbs, D. W.: Landslides in Seattle, Washington Division of Mines and Geology Information Circular 52, scale 1:31 680, 1974.

Van Genuchten, M. T.: A closed-form equation for predicting the hydraulic conductivity of unsaturated soils, Soil Sci. Soc. Amer. J., 44, 892-898, 1980.

Van Genuchten, M. T., Leij, F. J., and Yates, S. R.: The RETC code for quantifying the hydraulic functions of unsaturated soils, U.S. Environmental Protection Agency Report, EPA 600.2-91/065, 1991.

Varnes, D. J.: Slope movement types and processes, in: LandslidesAnalysis and Control, edited by: Schuster, R. L. and Krizek, R. J., Washington D. C., National Academy of Sciences, Transport. Res. Board, Special Report, 176, 11-33, 1978.

Waldron, H. H., Liesch, B. A., Mullineaux, D. R., and Crandell, D. R.: Preliminary geologic map of Seattle and vicinity, Washington, U.S. Geological Survey Misc. Geologic Invest. Map I-354, scale 1:31680, 1962. 